\title{
Methylenetetrahydrofolate Reductase
}

National Cancer Institute

\section{Source}

National Cancer Institute. Methylenetetrahydrofolate Reductase. NCI Thesaurus. Code C17311.

Methylenetetrahydrofolate reductase ( $656 \mathrm{aa}, \sim 75 \mathrm{kDa}$ ) is encoded by the human MTHFR gene. This protein plays a role in folate metabolism. 